\title{
A possible role for antibodies to tumour necrosis factor $\alpha$ and to endotoxin in the treatment of Reye's syndrome
}

\author{
M Odeh
}

Reye's syndrome is a severe and often fatal disease of unknown aetiology and pathogenesis that affects children after viral illness. ${ }^{1-4}$ It is characterised by encephalopathy and acute fatty degeneration of the liver. ${ }^{1-4}$ Epidemiological studies have suggested a close association with the development of Reye's syndrome and administration of aspirin to children infected with different types of viruses, where over $95 \%$ of children with the full blown syndrome have a history of aspirin ingestion. ${ }^{56}$

A role for endotoxin in the development of Reye's syndrome was suggested by Cooperstock et $a l,{ }^{7}$ who found increased concentrations of endotoxin in plasma from patients with Reye's syndrome. Furthermore, several investigators have shown that administration of a sublethal dose of endotoxin to fasted Sprague-Dawley rats produces metabolic changes and histological changes similar to those reported in Reye's syndrome. ${ }^{89}$ As endotoxin may cause most of its biological effects by the release of tumour necrosis factor $\alpha$ (TNF), ${ }^{10-14}$ and as many of the metabolic effects associated with Reye's syndrome may be mediated by $\mathrm{TNF}, 15$ it is reasonable to assume an important role for TNF in the pathogenesis of Reye's syndrome.

\section{Tumour necrosis factor $\alpha$}

TNF is a small polypeptide (also known as cachectin) released primarily by activated macrophages with pleotropic effects on biological and immunological processes. ${ }^{16-18}$ Although originally described as a cytotoxic factor, which induced haemorrhagic necrosis of transplanted tumours in mice, ${ }^{19}$ subsequently an expanded role has been shown for TNF as an important mediator of many inflammatory processes. ${ }^{17} 18$ TNF belongs to a class of hormone like molecules termed cytokines, a group of soluble factors that includes interferons, interleukins, and haematopoietic growth factors. These cytokines form a complex network of interactive signals that regulate their own production and the growth, differentiation or function of cells involved in inflammation, immunity, and haematopoiesis. It is now well recognised that TNF is a primary mediator in the patho- genesis of infection, tissue injury, inflammation, and lethal shock, ${ }^{10132021}$ and that it occupies a central position in the cytokine cascade, because this substance, more than any other, has been shown to reproduce virtually most (if not all) of the biological actions of endotoxin when injected. ${ }^{101314}$ It is synthesised by various activated phagocytic and non-phagocytic cells, including macrophages, monocytes, lymphocytes, natural killer cells, astrocytes, microglial cells of the brain, and Kupffer cells of the liver. ${ }^{21}$ A wide variety of infectious or inflammatory stimuli are capable of triggering TNF biosynthesis, for example, bacterial endotoxin, enterotoxin, toxic shock syndrome toxin-1, mycobacterial cord factor, viruses, C5a, fungal or parasitic agents, interleukins, and interferons, ${ }^{132021}$ where endotoxin is the most potent stimulator of TNF release from the monocyte/macrophage system. ${ }^{1820}$ Administration of human recombinant TNF that is virtually endotoxin free produces a variety of cardiovascular, haematological, inflammatory, and metabolic disorders, which are almost identical to those found in endotoxic or septic shock syndrome. ${ }^{1022-24}$ The strongest evidence implicating TNF as a principal mediator of multiple organ injury in infection is that anti-TNF antibodies prevent the sequelae of endotoxic and Gram negative septic shock and tissue injury. ${ }^{11-13}$

\section{TNF and Reye's syndrome}

Larrick and Kunkel ${ }^{15}$ were the first to hypothesise that Reye's syndrome may be caused by salicylate augmented release of TNF in children who are unusually sensitive to the toxic effects of these factors. They supported their hypothesis by the evidence that addition of aspirin to isolated macrophages results in enhanced production of TNF. ${ }^{15}$ In addition, it has been found that the median lethal dose for endotoxin is lower in young then in mature animals, and young animals are more susceptible to Gram negative bacterial infections. ${ }^{25}$ Although many host factors contribute to these findings, the greater susceptibility of young mice and rats to the toxic effects of TNF may be important. The fact that Reye's syndrome is

\author{
Correspondence to: \\ Dr M Odeh, PO Box 6477, \\ aifa 31063, Israel. \\ Accepted for publication \\ 10 January 1995 \\ Internal Medicine B \\ Center and Technion \\ Israel Institute of \\ Technology, Haifa, \\ Israel
}


seldom found in adults is consistent with increased susceptibility to TNF in children. ${ }^{15}$

Kilpatrick et $a l^{26}$ have recently demonstrated an animal model of Reye's syndrome by administration of lipopolysaccharide and aspirin to fasted rats, supporting by their findings the hypothesis of Larrick and Kunkel. ${ }^{15}$ They suggested a possible mechanism for the development of Reye's syndrome based on a rat endotoxin model. Children who develop Reye's syndrome may have a changed sensitivity or decreased capacity to clear endotoxin by the reticuloendothelial system, or both. The increased genetic or acquired sensitivity to endotoxin leads to endotoxin stimulated macrophage production and secretion of TNF. The administration of aspirin leads to enhanced macrophage production of TNF. Following the release of TNF into the circulation, this mediator binds to and interacts with target cells and produces numerous intracellular changes. The authors of the study already mentioned ${ }^{26}$ have seen increased acid proteolytic activity of serum samples of children with Reye's syndrome, ${ }^{27}$ suggesting the role of endogenous mediator such as TNF where in skeletal muscle this cytokine stimulates proteolysis and the release of amino acids.

The above findings are supported by the results of a recent study ${ }^{28}$ that showed increased plasma concentrations of TNF in acutely ill patients with Reye's syndrome but not in control subjects or recovered patients. Furthermore, the plasma concentrations of TNF were generally highest in the patients who died. These and other results of this study show that the pathological consequences of changes in patients who develop Reye's syndrome would appear when three conditions coexist $^{28}$ : (a) a viral illness that stimulates local TNF production by circulating monocytes or tissue fixed macrophages; (b) the addition of aspirin to amplify TNF production; and (c) a genetic or acquired loss of the protective inhibitory component of the response to high TNF values.

TNF participates in the pathogenesis of many liver diseases, ${ }^{29} 30$ where increased values of this cytokine may induce severe liver damage. It has also been shown to cause hepatocyte mitochondrial dysfunction, ${ }^{31}$ a characteristic feature of Reye's syndrome. Furthermore, this cytokine has recently been suggested to play a central part in the pathogenesis of hepatic encephalopathy, ${ }^{30}$ which also characterises Reye's syndrome. Another characteristic feature of Reye's syndrome is hypoglycaemia, and overproduction of TNF may induce profound hypoglycaemia. ${ }^{32-34}$ The mechanisms by which TNF induces hypoglycaemia are not fully understood. In Reye's syndrome, however, it may induce hypoglycaemia, partly, by the induction of severe liver damage.

Although TNF and endotoxin are important mediators in both bacterial sepsis and Reye's syndrome, the clinical manifestations of the two diseases are quite different. This may be related to the pleiotropic nature of TNF, which may have diverse biological actions and target cells in different diseases and different situations.

\section{Conclusion}

Taken together, the above data strongly suggest an important role for endotoxin and TNF in the pathogenesis of Reye's syndrome. This may possess an important clinical application; according to the results of the above study, ${ }^{28}$ plasma concentrations of TNF may be of an important prognostic value in Reye's syndrome. Furthermore, as already mentioned, all of the deleterious actions of TNF can be prevented by administration of anti-TNF antibodies, where these antibodies can also prevent the deleterious effects of endotoxin. ${ }^{11-13} 35$ In addition, it has recently been shown that monoclonal antibodies against endotoxin itself can prevent its deleterious actions. ${ }^{36-39}$ Thus, treatment with anti-TNF antibodies or with antibodies directed against endotoxin in patients with Reye's syndrome, may have potentially beneficial therapeutic effects in this serious and potentially fatal disease. The efficacy of antibodies to TNF and to endotoxin in the treatment of septic shock is still controversial. Reye's syndrome differs in its aetiology and nature from septic shock, however, and as patients with Reye's syndrome seem to have lost the protective adaptation to high concentrations of TNF, ${ }^{28}$ anti-TNF treatment may prove more effective in the treatment of Reye's syndrome than in septic shock.

1 Reye BDK, Morgan G, Baral J. Encephalopathy and fatty degeneration of the viscera: a disease entity in childhood. Lancet 1963; ii: 749-51.

2 Heubi JE, Partin JC, Partin JS, Schubert WK. Reye's syndrome: current concepts. Hepatology 1987; 7: 155-64.

3 DeVivo DC. Reye syndrome. Neurol Clin N Am 1985; 3: 95-115.

4 Reye's syndrome - United States, 1984. MMWR 1985; 34 13-6.

5 Starko KM, Ray CG, Dominguez LB, Stromberg WL, Woodall DF. Reye's syndrome and salicylate use. Pediatrics 1980; 66: 859-64.

6 Kilpatrick L. Biochemical manifestations of Reye syndrome: the role of aspirin. In: Feinman SE, ed. Beneficial and toxic effects of aspirin. 1st ed. Boca Raton, FL: CRC Press, 19fects of aspirin.

7 Cooperstock MS, Tucker RP, Baubles JV. Possible pathogenic role of endotoxin in Reye's syndrome. Lancet 1975 : 1272-4

8 Yoder MC, Egler JM, Yudkoff M, Chatten J, Douglas SD, Polin RA. Metabolic and mitochondrial morphological changes that mimic Reye syndrome after endotoxin administration to rats. Infect Immun 1985; 47: 329-31.

9 Kilpatrick-Smith L, Yoder MC, Polin RA, Douglas SD, Erecinska M. Endotoxin-induced changes in nitrogen metabolism. Res Commun Chem Pathol Pharmacol 1986; 53: 381-98.

10 Tracey KJ, Beutler B, Lowry SF, Merryweather J, Wolpe S, Milsark IW, et al. Shock and tissue injury induced by Milsark IW, et al. Shock and tissue injury induced by

11 Beutler B, Milsark IW, Cerami AC. Passive immunization against cachectin/tumor recrosis factor protects mice from lethal effects of endotoxin. Science 1985; 229: 869-71.

12 Tracey KJ, Fong Y, Hesse DG, Manogue KR, Lee AT, Kuo GC, et al. Anti-cachectin/TNF monoclonal antibodies prevent septic shock during lethal bacteremia. Nature 1987; 330: 662-4.

13 Tracey KJ, Lowry SF, Cerami A. Cachectin: a hormone that triggers acute shock and chronic cachexia. $\mathcal{F}$ Infect Dis 1988; 157: 413-20.

14 Beutler B. Cachectin in tissue injury, shock, and related states. Crit Care Clin 1989; 5: 353-67.

15 Larrick JW, Kunkel SL. Is Reye's syndrome caused by augmented release of tumor necrosis factor? Lancet 1986; ii: $132-3$.

16 Beutler B, Cerami A. Cachectin and tumor necrosis factor as two sides of the same biologic coin. Nature 1986; 320: as two

17 Cerami A, Tracey KJ, Lowry SF, Beutler B. Cachectin: a pluripotent hormone released during the host response to invasion. Recent Prog Horm Res 1987; 43: 99-112.

18 Le J, Vilcek J. Tumor necrosis factor and interleukin 1: 
cytokines with multiple overlapping biological activities. Lab Invest 1987; 56: 234-48.

19 Carswell EA, Old LJ, Kassel FL, Green S, Fiore N, Williamson B. An endotoxin-induced serum factor that causes necrosis of tumors. Proc Natl Acad Sci USA 1975; 72: $3666-70$.

20 Beutler B, Cerami A. Cachectin: more than a tumor necrosis factor. N Engl f Med 1987; 316: 479-85.

21 Tracey KJ, Vlassara H, Cerami A. Cachectin/tumor necrosis factor. Lancet 1989; ii: 1122-6.

22 Tracy KJ, Lowry SF, Fahey TJ, Albert JD, Fong Y, Hess $\mathrm{D}$, et al. Cachectin/tumor necrosis factor induces lethal shock and stress hormone response in the dog. Surg Gynecol Obstet 1987; 164: 415-22.

23 Johnson J, Meyrcik B, Jesmok G, Brigham KL. Human recombinant tumor necrosis factor alpha infusion mimics endotoxemia in awake sheep. $\mathcal{F}$ Appl Physiol 1989; 66: 1448-54.

24 Natanson C, Eichenholz PW, Danner RL, Eichacker PQ Hoffman WD, Kuo GC, et al. Endotoxin and tumor necrosis factor challenges in dogs simulate the cardiovasnecrosis factor challenges in dogs simulate the cardiovas-
cular profile of human septic shock. $\mathcal{F}$ Exp Med 1989; 169: cular profil

25 Morrison DC, Ulevitch RJ. The effects of bacterial endotoxins on host mediation systems. A review. Am $\mathcal{F}$ Pathol 1978; 93: 527-610.

26 Kilpatrick LE, Polin RA, Douglas SD, Corkey BE. Hepatic metabolic alterations in rats treated with low-dose endotoxin and aspirin: an animal model of Reye's syndrome. Metabolism 1989; 38: 73-7.

27 Douglas SD, Kilpatrick-Smith L, Polin RA, Kolski GB, Levy Y. Serum acid proteolytic activity in Reye syndrome. Lancet 1987; i: 221.

28 Corkey BE, Geschurind JF, Deeney JT, Hale DE, Douglas $\mathrm{SD}$, Kilpatric $\mathrm{L}$. $\mathrm{Ca} 2+$ responses to interleukin 1 and tumor necrosis factor in cultured human skin fibroblasts: possible implication for Reye's syndrome. 7 Clin Invest 1991; 87: 778-86.

29 Tilg H, Vogel W, Wiedermann CJ, Shapiro L, Herold M, Judmaier $\mathrm{G}$, et al. Circulating interleukin-1 and tumor necrosis factor antagonists in liver disease. Hepatology 1993; 18: 1132-8.

30 Odeh $M$. Endotoxin and tumor necrosis factor- $\alpha$ in the pathogenesis of hepatic encephalopathy. $f$ Clin Gastroenterol 1994; 19: 146-53.

31 Stadler J, Bentz BG, Harbrecht BG, Di Silvio M, Curran $\mathrm{RD}$, Billiar TR, et al. Tumor necrosis factor alpha inhibitis hepatocyte mitochondrial respiration. Ann Surg 1992; 216: $539-46$.

32 Vogel SN, Henricson BE, Neta R. Roles of interleukin-1 and tumor necrosis factor in lipopolysaccharide-induced hypoglyocaemia. Infect Immun 1991; 59: 2494-8.

33 Bagby GL, Lang CH, Hargrove DM, Thompson JJ, Wilson LA, Spitzen JJ. Glucose kinetics in rats infused with endotoxin-induced monokines or tumour necrosis factor. Circ Shock 1988; 24: 111-21.

34 Grunfelt C, Palladino MA. Tumor necrosis factor: immunologic, antitumor, metabolic, and cardiovascular immunologic, antitumor, metabolic, and

35 Silva AT, Bayston KF, Cohen J. Prophylactic and therapeutic effects of monoclonal antibodies to tumor necrosis factor- $\alpha$ in experimental gram-negative shock. F Infect Dis 1990; 162: 421-7.

36 Ziegler EJ, Fisher CJ Jr, Sprung CL, Straube RC, Sadoff JC, Foulke GE, et al. Treatment of gram-negative bacteremia and septic shock with HA-1H human monoclonal antibody against endotoxin. A randomized, double-blind, placebo-controlled trial. The HA-1A Sepsis Study Group. N Engl f Med 1991; 324: 429-36.

37 Baumgartner JD. Monoclonal anti-endotoxin antibodies for the treatment of gram-negative bacteremia and septic shock. Eur F Clin Microbiol Infect Dis 1990; 9: 711-6.

$38 \mathrm{Chmel} \mathrm{H}$. Role of monoclonal antibody therapy in the treatment of infectious disease. Am $\mathcal{F}$ Hosp Pharm 1990; 47 (suppl 3): S11-5.

39 Fisher CJ Jr, Zimmerman J, Khazaeli MB, Albertson TE Dellinger RP, Panacek EA, et al. Initial evaluation of human monoclonal anti-lipid A antibody (HA-1A) in patients with sepsis syndrome. Crit Care Med 1990; 18: 1311-5. 